\section{BIZTOSÍTÁSI PIAC ÉS SZOLGÁLTATÁSOK A LAKOSSÁG SZEMÉVEL}

Horváth Andrásés Paulovits Márton (a Deloitte Magyarország munkatársai)

\section{ÖSSZEFOGLALÓ}

A Deloitte Magyarország 2015-ben hozta létre a Biztosítási Index iparági felmérését azzal a céllal, hogy ügyfélmegkérdezésen alapulva adjon választ a biztosítási piacon jelenleg felmerülő kihívásokra. Az idén első ízben publikált, ettől kezdve évente megismételt, reprezentatív kutatás a szokásos demográfiai és piaci mutatókon túl számos releváns, egyéb háttérváltozó elemzését is lehetővé teszi. A komplex kérdőíves felmérés hosszú távon keresi arra a választ, hogy a magyar biztosítási piac milyen okokból kifolyólag van lemaradva az egy főre jutó díjbevételek és háztartásibiztosítás-piaci kiadások mentén nemcsak az európai átlagtól, hanem a visegrádi országok szintjétól is. A Deloitte-ot az a cél vezérli a kutatással, hogy hosszú távon maradandó értéket teremtsen, így a későbbiekben megismételt adatfelvételeken keresztül időbeli horizonton is alkalom nyíljon a lakosság biztosításokkal kapcsolatos piaci attitüdjének mérésére.

A Biztosítási Index, illetve a hasonló elven alapuló Deloitte-Scale BankIndex ${ }^{\mathrm{mm}}$ felmérés eredményei alapján az utóbbi három évben ugyan a bankokétól eltérően egyértelműen javult a biztosítók megítélése (és összességében is pozitívabb az összkép a biztosítókkal kapcsolatban), van azonban még mit javítani a szektor megítélésén, miközben a lakosság nagy része fontosnak tartja a tevékenységüket. Összességében jó hír, hogy legtöbben az öngondoskodás miatt kötnek biztosításokat, ugyanakkor az emberek közel harmada kifejezetten bonyolultnak tartja a biztosítási termékeket. A felmérés szerint a biztosítók számára (az ügyfél élethelyzetén alapuló) keresztértékesítés, illetve a biztosítással nem rendelkező társadalmi szegmensek minél pontosabb beazonosítása tartogathat növekedési potenciált a következő években.

Elemzésünkben összefoglaljuk az utóbbi évek biztosításpiaci adatait: elsősorban az egy fơre vetített biztosításpiaci díjbevételeken és a háztartások vagyoni helyzetének bemutatásán keresztül, Magyarország és az Európai Unió tekintetében.

\section{SUMMARY}

In 2015 Deloitte Hungary created the Insurance Index, a sectorial survey based on client opinion polling, in order to react to the main challenges that arise on the market of insurance products. The representative survey published this year for the first time will be followed by annual surveys. The goal of the survey is to facilitate the analysis of relevant background variables besides the usual demographic and market data. The long-term aim of this complex poll is to reveal the reasons behind the backwardness of the Hungarian insurance sector in comparison with not only the European average but the countries of the Visegrad Group with regard to per capita insurance premiums and household insurance spending. The goal of Deloitte with this survey is to create lasting value for the long-term in order to facilitate the measurement of the market attitude of the population regarding insurance products, taking into account the time horizon via recurring data collection.

Due to the results of the Insurance Index - as well as the Deloitte-Scale Bankindex ${ }^{\text {tim }}$ survey that is based on a similar principle - in the last three years, unlike the perception of banks, that of insurance companies has improved considerably (and the general image of insurance companies is more positive), but still there is room for improvement regarding the judgment of the sector, meanwhile the majority of the population believes that activity of insurers is important. All in all, good news is that the majority takes out an insurance for self-care, though one third of the people considers insurance products especially difficult. According to the survey there is potential for growth for insurance companies in the next few years in cross-selling (based on the client's real-life situation), as well as in the precise identification of social segments currently not taking out insurance policies.

In our analysis we summarize the insurance market data of the previous years: principally through the demonstration of per capita insurance premiums and household wealth, with regard to Hungary and the European Union.

Kulcsszavak: biztosítási index, biztosítási piac, háztartások megtakarítása Key words: Insurance Index, Insurance Market, Household Saving

\section{JEL: G22, D14}

DOI: $10.18530 / \mathrm{BK} .2016 .4 .86$

http://dx.doi.org/1018530/BK.2016.4.86 


\section{A magyar és az európai uniós biztosítási piac összevetése}

Az alábbiakban makrogazdasági szinten vizsgáljuk meg a hazai biztosítási piacot, a magyar adatokat összevetve néhány régiós, illetve nyugat-európai ország adataival. A mintában összességében 26 európai ország adatait használtuk fel ${ }^{1}$, a kiinduló bázist az EUROSTAT nyújtotta lehetőségek biztosították. A vizsgálatnak alapvetően két fó fókusza van: egyrészről bemutatjuk, hogy a háztartások pénzügyi vagyonában hogyan, mekkora arányban jelennek meg a különböző biztosítások és biztosítással kapcsolatos tartalékok, másrészről pedig megvizsgáljuk, hogy a biztosítói díjbevételek egy före vetítve hogyan alakulnak az egyes országokban. Az elemzés célja a magyar biztosítási piac fejlettségének összevetése a többi európai országéval, illetve a magyar piac elhelyezése több különböző mutató mentén. A piaci pozíció meghatározása után arra keressük a válaszokat, hogy miért látunk lemaradást a többi országhoz képest.

\section{A háztartások pénzügyi vagyonának elemzése}

Az elemzés első részében elvégezzük a háztartások pénzügyi vagyonának, ezen belül pedig a háztartási vagyonelemek biztosításokban koncentrált részének vizsgálatát.

A háztartások teljes pénzügyi vagyonának GDP-hez viszonyított arányát az 1. ábra szemlélteti. GDP-arányosan a legnagyobb pénzügyi vagyonnal Hollandia rendelkezik, mögötte található Belgium és Svédország. A pénzügyi vagyon mindhárom esetben meghaladja a folyó áron kalkulált GDP két és félszeresét. Magyarország - bár az említett országoktól jelentősen elmarad a maga 119 százalékos értékével - a régióban meglehetősen előkelő helyen áll.

1. ábra: Háztartások pénzügyi vagyona a GDP arányában 2015-ben (\%)

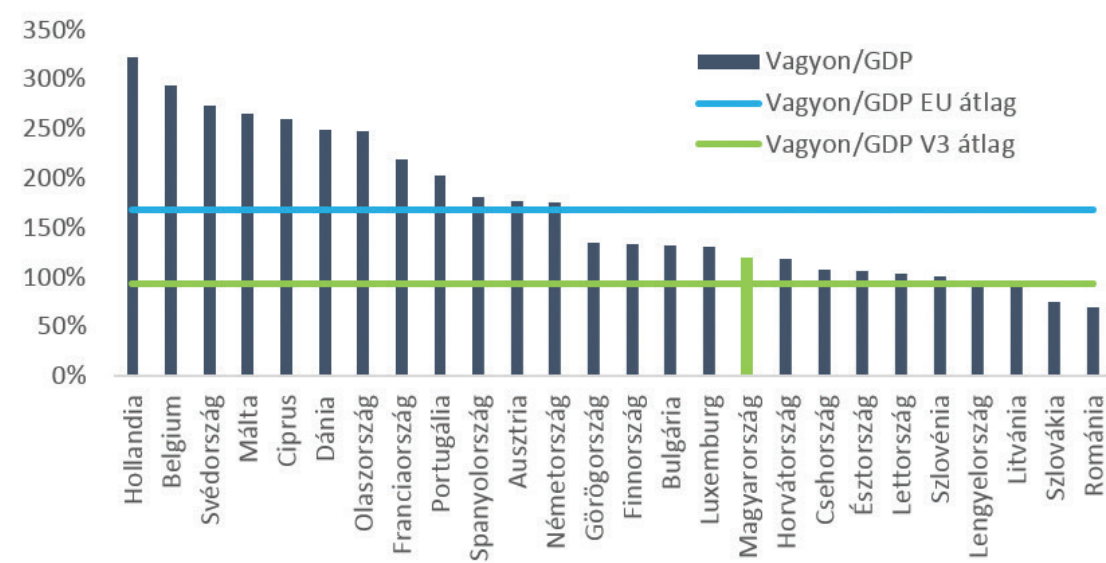

Forrás: EUROSTAT, European sector accounts database
A vizsgált európai országok pénzügyi vagyonának értéke átlagosan a GDP 169 százalékát teszi ki, a szélső értékek 70 és 322 százalék. Ugyanakkor a többi visegrádi ország a GDP-arányos pénzügyi vagyon tekintetében valamelyest lemaradt hazánktól: átlagosan 93 százalékon áll a háztartások GDP-hez mért pénzügyi vagyona.

Összességében tehát kijelenthető, hogy a magyar háztartások pénzügyi vagyonának szintje meghaladja a régiós és a visegrádi országok átlagának értékét, ugyanakkor az EU-átlagtól még elmarad a magyarok által megtakarított összeg a GDP arányában.

A GDP-vel történő viszonyítással némileg hasonló összképet mutat a 2. ábrán a háztartások egy före jutó pénzügyi vagyonának vizsgálata is. Egy kivétellel: Luxemburg itt a harmadik helyre kerül, ugyanis az elöző táblázatban elfoglalt tizenharmadik helye a GDP magas értékének tudható be. Ebben a vonatkozásban a szórás nagyobb: a legjobban teljesítő Hollandia 129 ezer eurós értéke „áll szemben” az 5,5 ezer eurós román értékkel.

2. ábra: Háztartások egy före jutó pénzügyi vagyona 2015-ben (EUR)

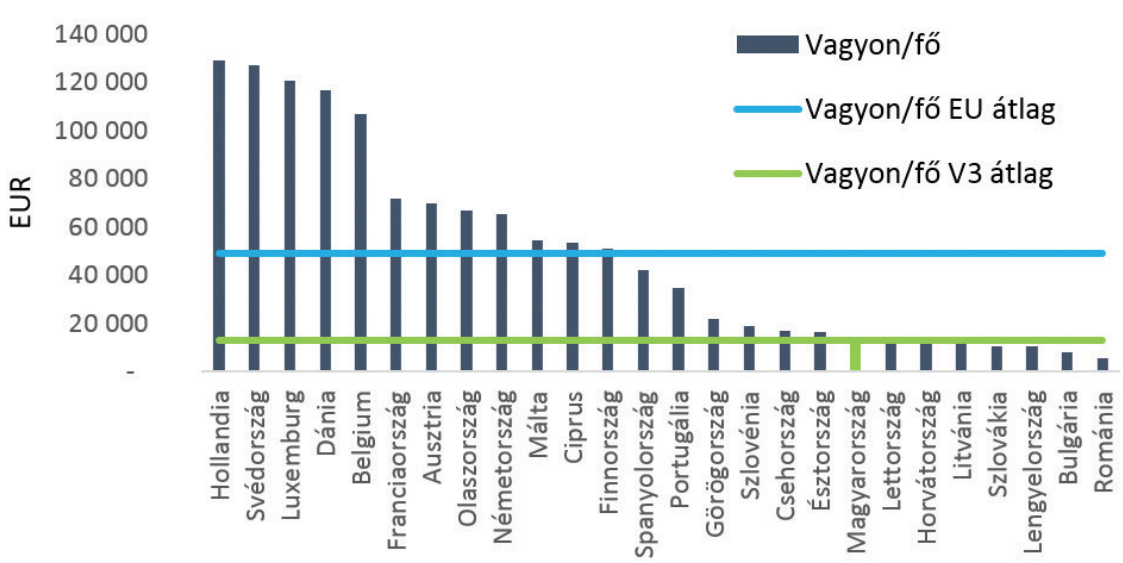

Forrás: EUROSTAT, European sector accounts database

Az egy főre jutó magyar megtakarítások nagysága (12,9 ezer euró) a vezető országokétól jelentősen elmarad, azonban a régióban csupán Szlovénia és Csehország áll előkelőbb helyen. Horvátországot, Lengyelországot, Szlovákiát és Romániát sikerült magunk mögé utasítani. Az átlagos, egy före jutó pénzügyi vagyon nagysága európai átlagban 48,9 ezer euró, ettől a régió összes országa jelentősen elmarad. A visegrádi országok átlaga Magyarország nélkül számítva mintegy 12,9 ezer euró. 
A háztartások vagyonának/pénzügyi eszközeinek szerkezetét vizsgálva alapvetően a biztosításokat érintően két kategóriát különíthetünk el: az életbiztosítás jellegű, illetve a nem-életbiztosítás jellegű díjtartalékokat. Az előbbi kategória jelentékenyebb részét képezi a háztartások vagyonának: a vizsgált országok tekintetében átlagosan a GDP 18,6 százalékát teszi ki, szemben a nem-életbiztosítás jellegű, a GDP 2 százalékát kitevő vagyontömeggel (3. ábra).

3.ábra: Háztartások pénzügyi vagyonának életbiztosítási díjtartalékban lévő része a GDP-hez viszonyítva 2015 (\%)

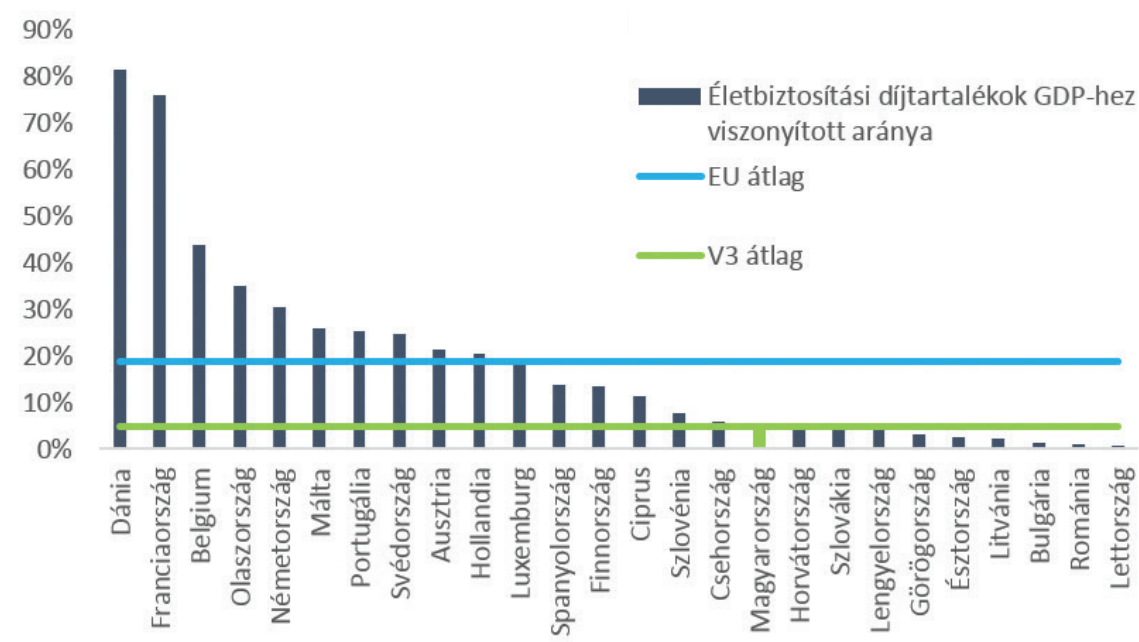

Forrás: EUROSTAT, European sector accounts database

Magyarország a maga 5 százalékos GDP-arányos értékével előkelő helyet foglal el a régióban. Az elmaradás azonban jelentős mind az átlagos értéktől, mind pedig a fent bemutatott, elsősorban nyugat-európai országoktól. Az első helyen álló Dániában például a GDP 80 százalékát teszik ki az életbiztosítás jellegű megtakarítások, bár az is igaz, hogy ehhez egy - már az 1. és 2. ábrákon bemutatott - GDP-arányosan jelentős vagyontömeg társul

A biztosításokat érintő másik releváns vagyonelem a nem-életbiztosítás jellegű dijtartalékok. Ide tartozik a nyugdíjbiztosítás kivételével minden, az életbiztosítás kategóriájába be nem sorolható elem. Látható a 4. ábrán, hogy ennek a GDP-hez viszonyított aránya alapvetően jóval alacsonyabb az életbiztosítás jellegű vagyonelemnél, a legmagasabb arányt képviselő Németországban is csupán a GDP 10,7 százalékát teszik ki az ilyen jellegű befektetések. A vizsgált minta átlagos értéke 2,32 százalék, Magyarországon ehhez képest 0,9 százalék a nem-életbiztosítás jellegü befektetések aránya a teljes vagyonon belül. 4.ábra: Háztartások pénzügyi vagyonának nem-életbiztosítási díjtartalékban lévő része a GDPhez viszonyítva 2015 (\%)

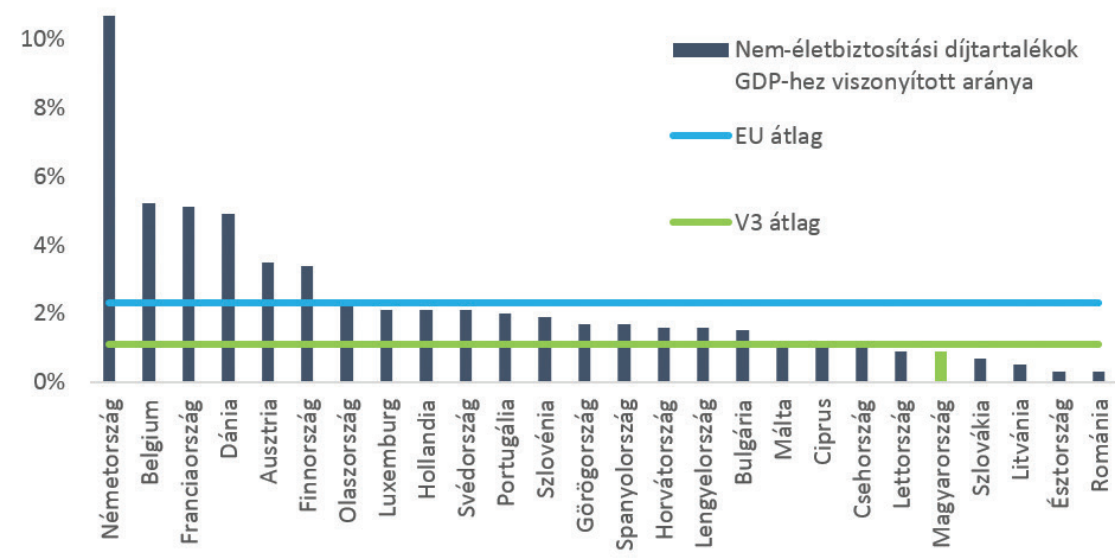

Forrás: EUROSTAT, European sector accounts database

A fentiek alapján tehát több mutatóban is úgy tűnik, hogy Magyarország, bár nem éri el az európai átlag szintjét, mégis a régió éllovasai között teljesít 2015-ben - és hosszabb időtávlatban is. Ugyanakkor a háztartások pénzügyi eszközeinek szerkezetét vizsgálva már összetettebb kép rajzolódik ki biztosításpiaci szempontból: a háztartások pénzügyi eszközeiben Magyarországon legnagyobb arányban a betétek, befektetési jegyek és tulajdoni részesedések szerepelnek. Az utóbbi évek kamatcsökkentési periódusainak köszönhetően a vagyonelemeken belül komoly átrendeződés volt megfigyelhető: a háztartások - reagálva a piaci folyamatokra - az alacsony hozamú, ám biztonságosabb betéti termék felől egyre inkább a befektetési jegyek és állampapírok felé fordították a figyelmüket.

A biztosítási megtakarítások, illetve biztosítástechnikai tartalékok szerepe a háztartások pénzügyi vagyonelemei közt összességében itthon elmarad az európai átlagtól, sőt a visegrádi országok szintjétől is - együttvéve a biztosítástechnikai tartalék instrumentumok szintjén figyelhető meg a pénzügyi eszközök szerkezetén belüli legnagyobb eltérés az uniós országokhoz képest.

Ez azt jelenti, hogy a lakosság pénzügyi eszközeiből kevesebb részt allokál a biztosításpiaci termékekre általában, miközben a pénzügyi eszközök szintje ugyanakkor lehetôvé tenné a magasabb igénybevételt. A biztosítási tartalékok (élet és nem-élet összesen) teljes vagyonállományon belüli aránya 2005-2015 között 5,35-7,06 százalék közötti szinten mozgott Magyarország esetében, átlagosan az utóbbi 10 évben alig haladta meg a 6 százalékot.

A többi visegrádi országnál ez az arány 2005-2015 között 7,21-9,13 százalék átlagos szin- 
teken, míg a teljes EU-s átlag 17,59-20,93 százalék között alakult. Ha a hozzánk legközelebb eső lengyel piaci adat értékéhez viszonyítunk, akkor mintegy 0,89-1,08 százalék a lemaradásunk a pénzügyi vagyonelemek szintjén - a hosszú távú átlaghoz, illetve a legfrissebb adathoz viszonyítva.

Ez számszerüsítve azt jelenti, hogy a háztartások pénzügyi eszközeinek 2015. év végi értékére, 40,581 milliárd forintra vetítve mintegy 360-440 milliárd forint többletallokáció lenne szükséges biztosításpiaci termékekbe a háztartások részéről annakérdekében, hogy - feltételezve egy stabil pénzügyi eszköz szintet - legalább a lengyel szintet elérjük a következő években.

\section{Biztosítói díjbevételek alakulása}

Ahogyan a bevezetőben láthattuk, az elemzés másik ágát a biztosítói díjbevételek alakulásának vizsgálata jelenti, így nemcsak a háztartások oldaláról járjuk körül a piacot, hanem a biztosítói díjbevételek szintjén is. Ebbe az elemzésbe ugyanazon 25 ország adatait vettük alapul (Litvánia esetében nincs egyenszilárdságú nemzetközileg publikált adat).

Az adatok alapján az látható, hogy a lakosság pénzügyi vagyonában a különböző biztosítások értékének nagysága összefüggést mutat adott ország biztosítói díjbevételeinek GDP-arányos nagyságával. Míg a magyar díjbevétel a GDP 2,52 százalékát teszi ki, az 5. ábrán a mintába bekerült országok átlagos értéke 5,09 százalék. A lemaradás az élvonalhoz képest jelentős, a finn díjbevétel például valamivel több, mint a GDP tizedére rúg. Ebben a mutatóban a V3 átlag szintjét (2,96\%) sem éri el a magyar érték.

5. ábra: Teljes biztosítói díbbevétel a GDP arányában 2015

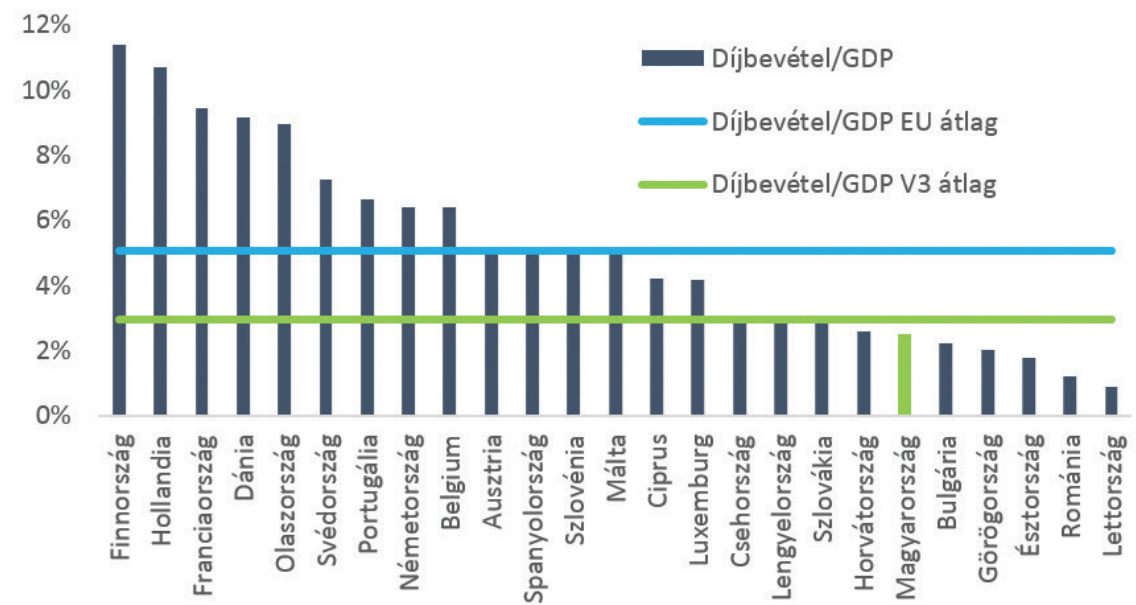

A díjbevételt megvizsgáltuk másik oldalról is, így az adott ország teljes éves biztosítói díjbevételét az ország lakosainak számára vetítve megkaptuk az egy főre eső díjbevétel nagyságát. A 6. ábrán látottakhoz képest hasonló sorrend rajzolódik ki, azonban a különbségek így is szembetűnőek: a nagyjából 4300 euró/fő éves biztosítói díjbevételü Finnország és a 97 euró/fő éves biztosítói díjbevételü Románia között negyvenötszörös a különbség. A magyar érték (273 euró/fö) jócskán elmarad nemcsak az élvonaltól, de a visegrádi országok átlagos szintjétől is (410 euró/fó).

6. ábra: Egy före eső biztosítói díjbevétel 2015-ben (EUR)

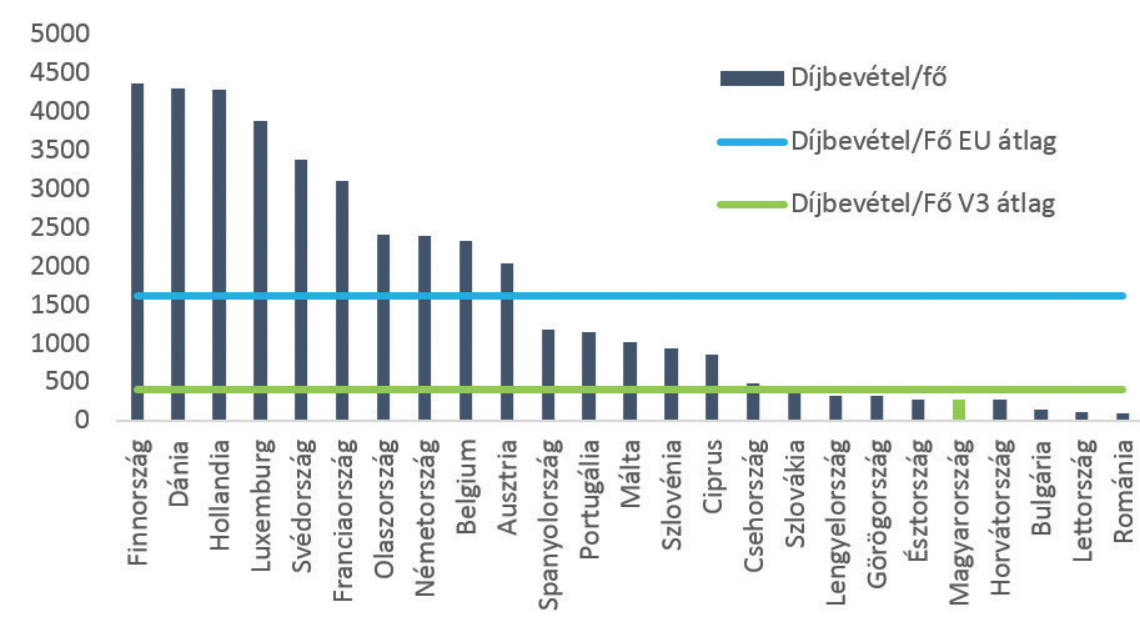

Forrás: EUROSTAT, European sector accounts database

A biztosítói díjbevételeket tovább boncoltuk: először az életbiztosítási díjbevételt vettük górcső alá. A 7. ábrán a két szélsőérték között jelentős eltérések tapasztalhatók, a sorrend hasonló a GDP-arányos teljes biztosítói díjbevételekhez.

Magyarország ebben a mutatóban szinte megegyezik a többi visegrádi ország átlagos értékével: az életbiztosításokhoz kapcsolódó GDP-arányos díjbevétel mintegy 1,34 százalék a GDP arányában. 
7. ábra: Életbiztosításból származó díjbevétel a GDP arányában 2015 (\%)

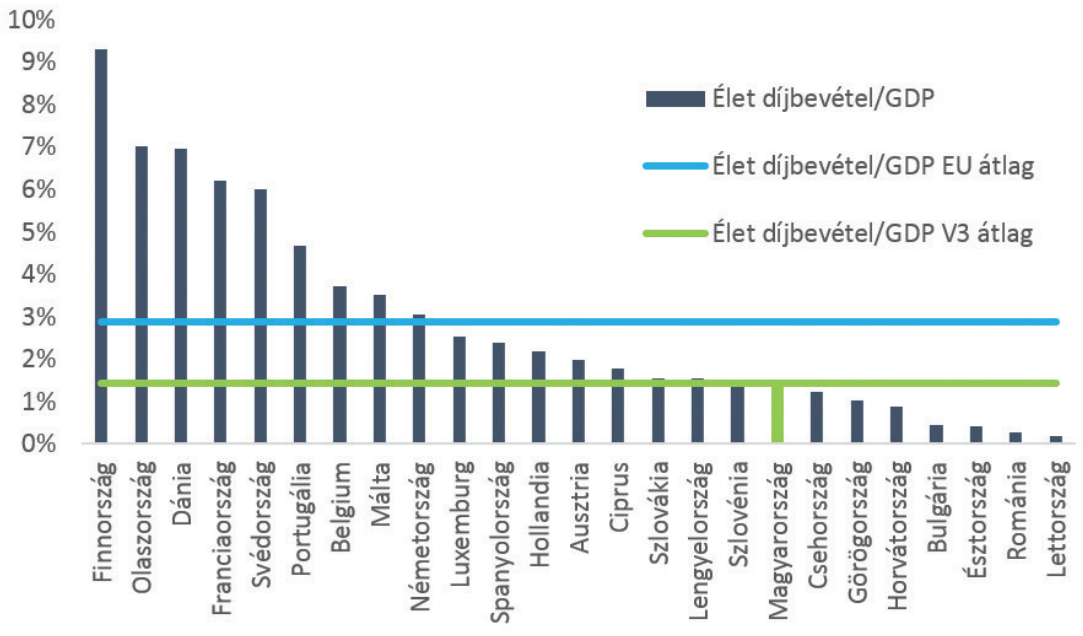

Forrás: EUROSTAT, European sector accounts database

A nem-életbiztosításból származó díjbevételek a teljes dijjbevétel kisebb hányadáért felelősek. Mindenképpen feltűnő különbség a 7. ábrához képest az ilyen jellegű bevételek alacsonyabb szórása a 8. ábrán: a második helyen álló Szlovénia bevétele mintegy ötszöröse az utolsó helyen álló Lettország díbevételének - egyedül Hollandia értéke esik ki az európai adatok közül. Magyarország a hátsó zónában helyezkedik el, a visegrádi országok átlagértéke alatt.

8. ábra: Nem-életbiztosításból származó díjbevétel a GDP arányában 2015-ben (\%)

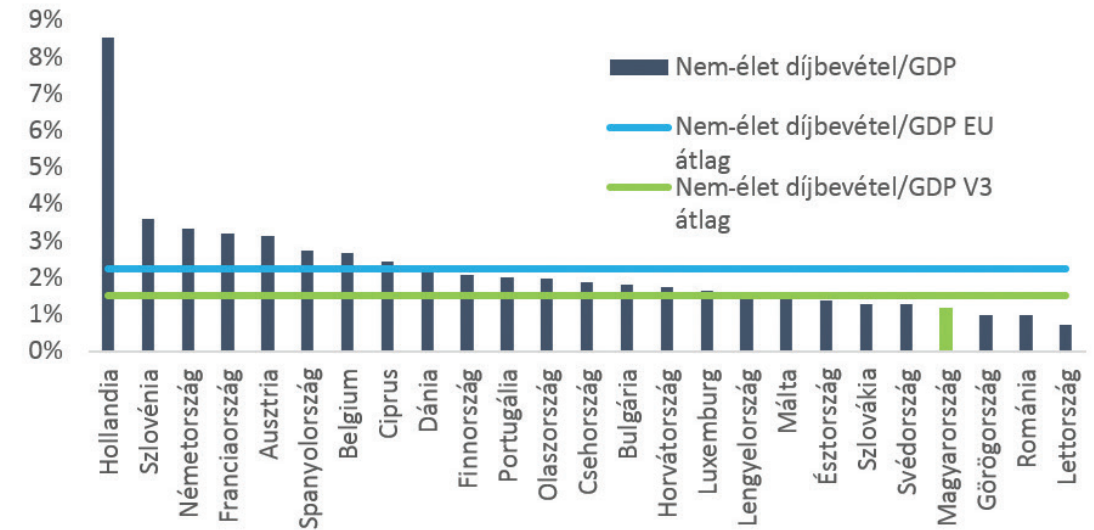

Forrás:EUROSTAT, European sector accounts database
A 9. ábra az egy före jutó életbiztosításból származó díjbevételt szemlélteti a már korábban vizsgált országok tekintetében. Ahogy korábban az egy före vetített elemzéseknél, itt is megfigyelhető az értékek jelentős szóródása: a magyar értéket (146 euró/fö) a visegrádi országok hasonló értékei némileg meghaladják, Szlovákia értéke 223 euró/fó. A régió országainak az átlagtól való lemaradása azonban így is szembeötlő, az egy főre eső átlagos érték a fenti mintán számolva 955 euró.

9. ábra: Egy fơre jutó életbiztosításból származó díjbevétel 2015-ben (EUR) 4000

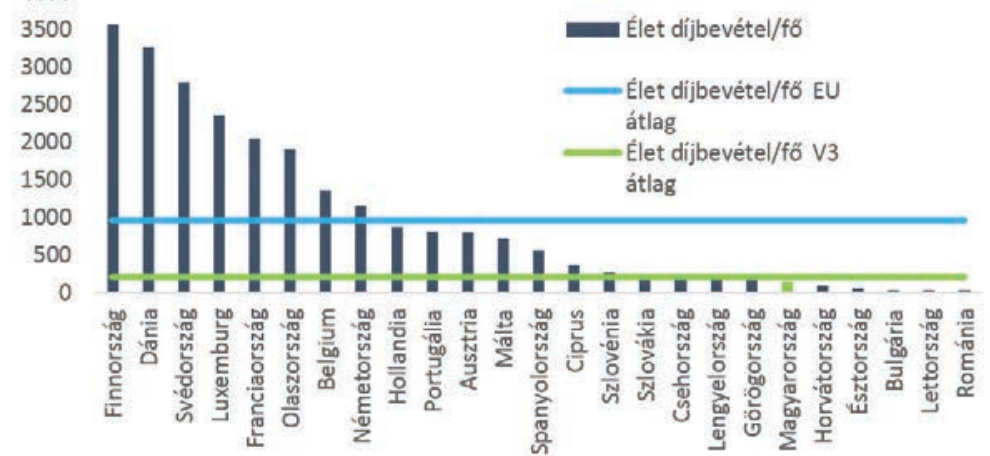

Forrás: EUROSTAT, European sector accounts database

A nem-életbiztosításból származó, egy före jutó díjbevételek tekintetében a 10. ábrán két, a díj nagyságában szignifikánsan különböző csoport különíthető el egymástól: az első, 3400 és 658 euró/fö között változó, jellemzően nyugat-európai országokat (kivéve Szlovéniát és Ciprust) magába foglaló csoport díjbevételei jelentősen meghaladják a 346 és 77 euró/fö között mozgó, jellemzően kelet-európai és balti országokat tömörítő csoportét. Magyarország az utóbbi csoportban található a maga 128 euró/fö értékével, így 531 euróval marad el a vizsgált országok átlagos értékétől.

10.ábra: Egy före jutó nem-életbiztositásból származó díjbevétel 2015-ben (EUR)

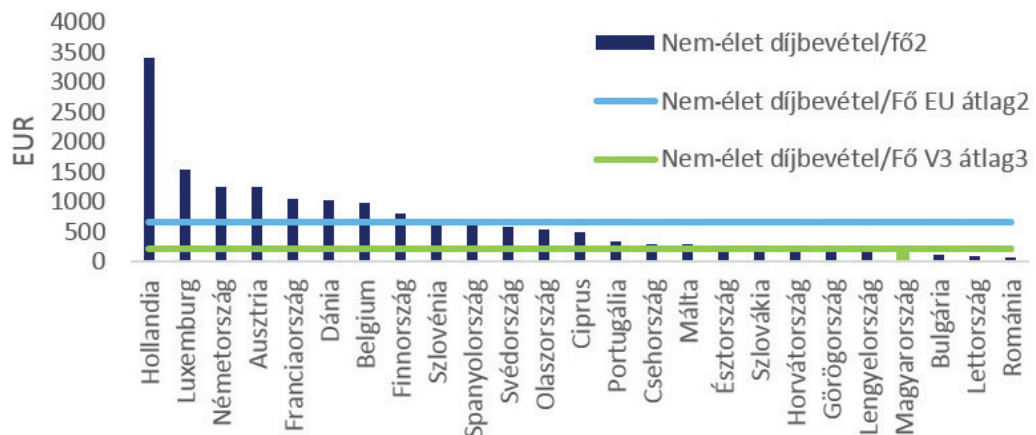

Forrás: EUROSTAT, European sector accounts database 
Összességében azt látjuk, több oldalról is megvizsgálva a biztosítási piacok értékeit, hogy bár a háztartások pénzügyi eszközeinek szintje GDP-arányosan nincs komoly elmaradásban a régiós és európai uniós szintekhez képest, a pénzügyi eszközök szerkezetében kisebb súllyal vesznek részt a biztosításpiaci termékek. Ez igaz akár a GDP-hez viszonyítva, akár egy főre vetítve is.

Hasonló tendenciák figyelhetők meg abban az esetben, amikor a biztosítói díjbevételek nagyságát vizsgáljuk. Felmerül a kérdés, hogy milyen okokkal magyarázható ez a tendencia - még akkor is, ha lehetnek különbségek az egyes országok pénzügyi eszköz elemek besorolási metódusai között. A mi feltevésünk az, hogy pusztán gazdasági/szabályozói vagy fejlettségi eltérésekkel nem magyarázható a különbség, így másfajta módon is szükséges vizsgálni a differenciákat.

Ennek egyik lehetséges módja a kulturális és attitűdbeli minták azonosítása. Éppen ezért került létrehozásra a Biztosítási Index, amely alternatív aspektusból, a lakosság szemszögéből vizsgálja a biztosítási piac folyamatait, megítélését és a termékek választását/használatát.

\section{Az utóbbi évek tapasztalatai a biztosítási piac és termékek lakossági megítélésében}

Mielőtt összefoglalnánk az elvégzett kutatás eredményeit, néhány alapvető lakossági sajátosságra rámutatunk a biztosítási piaccal kapcsolatban. Az adatok, eredmények forrása a Deloitte-Scale Bankindex ${ }^{\text {Tx }}$ kutatása, amely a pénzintézetek és bankok, valamint az ügyfeleik kapcsolatát, valamint a lakosság pénzpiaci attitüdjét, annak változásait méri, ugyanakkor biztosítási termékekkel kapcsolatos, specifikus részt is tartalmaz. Ez a kutatás több mint 7 éve zajlik, évente 6000 személyes interjún keresztül, országos, reprezentatív mintán. ${ }^{2}$ A megkérdezettek reprezentálják a 18 évnél idősebb magyarországi lakosokat.

\section{Összességében átlagosan másfél biztosítással rendelkeznek a} háztartások, ami alacsony számnak tekinthető.

A Deloitte-Scale Bankindex ${ }^{\mathrm{mm}}$ adatai szerint a háztartások átlagosan mintegy 40 százaléka rendelkezett valamilyen biztosítással saját bevallása szerint a 2012-2015-ös időtávon (figyelembe véve az egyes évek felmérési adatait). A biztosítással rendelkező háztartások aránya alig változott az utóbbi 4 év adatait vizsgálva: 2012-2015 között nagyjából konstans piacot figyeltünk meg, enyhe csökkenéssel. Összességében átlagosan másfél biztosítással rendelkeznek a háztartások, ami alacsony számnak tekinthető, figyelembe véve az elérhető termékek és biztosítási megoldások számát.

Regionális szempontból a legerősebb biztosítási penetráció a háztartások körében Közép- és Nyugat-Dunántúlon figyelhető meg. Szintén regionális érdekesség, hogy a község településtípuson belül a városnál és megyeszékhelynél, de még Budapestnél is magasabb a penetráció - míg ugyanakkor jellemzően itt is csupán egy terméket vesznek igénybe a háztartások.

A teljes népességen belül 55-64 éves kor között a legmagasabb a biztosítással rendelkezők aránya. A végzettség emelkedésével párhuzamosan nő a biztosítások jelenléte is: főiskolai vagy egyetemi végzettséggel rendelkezők körében több mint kétszer akkora a biztosítások igénybevétele, és az átlagos termék darabszáma is magasabb számot mutat.

A legfontosabb differenciáló tényező a biztosítási termékkel kapcsolatban a jövedelmi szint nagysága, ugyanakkor az is látható a makroadatokból, hogy a többi visegrádi országhoz képest is van elmaradás - tehát a tehetősebbek is inkább alulbiztosítottak.

Termékek szintjén a lakásbiztosítás foglalja el az első helyet, amit a kötelező gépjármü-felelősségbiztosítás (kgfb) és az életbiztosítás követnek - összhangban a piacon látható adatokkal. Az elmúlt évek adataiból megállapítható az is, hogy Magyarországon a nem-életbiztosítások területén a vagyonbiztosítások aránya a meghatározó (41\% az elmúlt 5 év átlaga), amit a kgfb (25\%), majd a casco és egyéb biztosítások követnek (elmúlt 5 év átlaga 17-17\%).

A lakás és a kgfb stagnálása mellett az utóbbi években az életbiztosítások enyhe csökkenése (1,1 százalékpont visszaesés az utóbbi négy évben) figyelhető meg. A Nyugat-Dunántúl dominanciája itt is tetten érhető: jelentősen magasabb a két és három biztosítással (élet és nem-élet) rendelkező háztartások aránya a többi régióhoz képest. Érdekesség, hogy a nyugat-dunántúli portfólió fiatalabb is az országos átlagnál - több mint 50 százalék az utóbbi öt évben kötötte biztosítását, míg a Dél-Alföldön a megkötött biztosítások átlagos kötési ideje több mint 10 év. Érdekesség továbbá, hogy a dunántúliak körében alacsonyabb azoknak az aránya az országos átlaghoz képest, akik szerint a biztosítások díja korrekten van megállapítva a nyújtott szolgáltatáshoz képest - ugyanez igaz az általános termékmegítélésre vonatkozóan is.

A háztartások több mint 45 százaléka kevesebb mint 5 éve kötötte a biztosítását (élet és nem-élet összevonva), mintegy 68 százalékuk pedig az utóbbi 10 évben. A portfólió egyre inkább öregszik, míg 2012-ben az átlagos biztosítási termék kora 5,9 év volt, addig ez az érték 2015 második felében már 7,7 év. Amennyiben kifejezetten az életbiztosítások adatait vizsgáljuk, azt láthatjuk, hogy átlagosan 14 évre terveznek a magyar háztartások ezen termékek tekintetében, ez az érték alig emelkedett az utóbbi években.

Az életbiztosítások nagy részét, az európai trendekkel ellentétben, a megtakarítással kombinált termékek adják: a Deloitte-Scale Bankindex ${ }^{\mathrm{Tm}}$ felmérése szerint a háztartások 55 százaléka ilyen típusú életbiztosítással rendelkezik. Ezt a magyar sajátosságot legfőképpen az magyarázza, hogy a kockázati terméket jellemzően az ügyfelek csak kötelezően kötik (pl. hiteltermékekhez csatolva), illetve a befektetési biztosítási termékeket a hosszú lejáratú megtakarítási struktúrákat megillető kamatadó-mentesség is vonzóbbá teszi a lakosság számára. Azt a tényt sem szabad figyelmen kívül hagyni, hogy ezen termékekre a múltban további szja-kedvezmény is igénybe vehető volt, ami ugyancsak növelte a megtakarítással kombinált 
termékek attraktivitását.

Ebben a szegmensben tehát ugyanazt kaptuk eredményül, amit egyébként a piaci adatokon keresztül is megfigyelhetünk: az életbiztosítási termékek klasszikus kockázati biztosítási jellege kevésbéérvényesül Magyarországon. Ennek megfelelően a háztartások, ha életbiztosítási terméket választanak, akkor inkább megtakarítási megfontolásból teszik ezt.

A termékkel kapcsolatos penetráció mellett számos olyan kérdést is vizsgáltunk az utóbbi években, amely a biztosítási díjakkal, ügyintézéssel kapcsolatos attitüdöket méri a háztartások körében. Az emberek több mint 64 százaléka egyetért abban, hogy a biztosítás díja korrekten van megállapítva a nyújtott szolgáltatáshoz képest, és csak mintegy 6,6 százalék ítéli túlárazottnak a biztosítási termékeket. 2015-ben azoknak az aránya, akik szerint korrekt a biztosítók által megállapított díjazás, több mint 72 százalék volt. Ez alapján tehát az alacsonyabb biztosítási igénybevételt a háztartások részéről nem feltétlenül árérzékenység jelenti.

Ennél is erősebb a kép a tekintetben, hogy mennyire tartják egyszerünek az ügyintézést: több mint 69 százalék szerint egyszerű az ügyintézés, emellett pedig mintegy 68 százalék szerint még gyors is. Több mint 70 százalék azoknak az aránya, akiknek összességében megfelel a termék. Ezzel párhuzamosan jól kimutatható, hogy 75 százalék a jövőben nem is gondolkodik biztosítóváltáson. Ezzel szemben csak 3,5 százalék tervezi a közeljövőben a meglévő életbiztosítás mellé egy új biztosítás kötését.

Összességében az utóbbi évek felmérései alapján az látható, hogy a háztartások biztosítottsági szintje alacsony, szignifikánsan alig változott, illetve a portfólió egyre inkább öregszik. A lakásbiztosítás és a kfgb kimagasló helyet foglal el a háztartások portfóliójában, valamint életbiztosítás területen a befektetéshez kötött életbiztosítások sokkal nagyobb részt képviselnek a kockázati biztosításoknál. A biztosításpiaci termékekkel, szolgáltatásokkal kapcsolatos lakossági megítélés alapján elmondható, hogy kevesebb ellenérzése van a lakosságnak a biztosítókkal szemben a bankokhoz képest, valamint általában elégedettek a termékek árazásával és a kiszolgálással.

\section{A biztosítási piac legfrissebb adatai}

Az első ízben elkészített Biztosítási Index a Deloitte Magyarország reprezentatív felmérése a lakossági biztositási szolgáltatások használatáról. Az Index a biztosítási szolgáltatás igénybevételét vizsgálja különböző elemzési szempontok alapján; a szokásos demográfiai és piaci mutatókon túl számos releváns háttérváltozó (pl. piaci változások nyomon követése, ügyfél-szegmentáció, információgyüjtés formái, értékesítési csatornák használata terméktípusonként, termékfejlesztés) elemzését is lehetővé teszi.

A rendszeres, ügyfélmegkérdezésen alapuló iparági elemzés képes választ adni a biztosítási piacon felmerülő kihívásokra. Létrehozásával a Deloitte tavaly fiatalon elhunyt partnerének Szép Péternek (1970-2015) korábbi munkásságát kívánja tovább folytatni.

A Biztosítási Index célja, hogy átfogó képet adjon a biztosítók, valamint a biztosítottak közötti kapcsolat minőségéről. Az adatfelvétel évi két alkalommal, 1000 fös országos, a 18 évnél idősebb magyarországi lakosokra reprezentatív mintán történik, amit az új biztosítást kötők telefonos megkérdezése egészít ki. Ahogy a bevezetőben is említésre került, a Deloitte azért hozta létre a Biztositási Indexet, hogy folyamatosan mérni tudja különböző aspektusok mentén a lakosság biztosítási piaccal és biztosítási termékkel kapcsolatos percepcióját. Ezeken az információkon keresztül is jobban megérthetőek a háztartások termékválasztásai.

A Biztosítási Index célja, hogy átfogó képet adjon a biztosítók, valamint a biztosítottak közötti kapcsolat minőségéről. Az adatfelvétel évi két alkalommal, 1000 fös országos, a 18 évnél idősebb magyarországi lakosokra reprezentatív mintán történik, amit az új biztosítást kötők telefonos megkérdezése egészít ki. Ahogy a bevezetőben is említésre került, a Deloitte azért hozta létre a Biztosítási Indexet, hogy folyamatosan mérni tudja különböző aspektusok mentén a lakosság biztosítási piaccal és biztosítási termékkel kapcsolatos percepcióját. Ezeken az információkon keresztül is jobban megérthetőek a háztartások termékválasztásai.

A fogalom meghatározása láthatóan nem tér ki arra, hogy a tevékenység végzése milyen módon és milyen eszközzel történhet. Ebből azt az elvszerű következtetést lehet levonni, hogy a jogalkotó a közvetítés módjára, a használt eszközre tekintet nélkül ugyanazon szabályozást rendeli használni. Vagyis a Bit. jelenlegi szabályozása alkalmazandó a személyesen, illetve az elektronikus felületek segítségével végzett tevékenységre egyaránt. Az egyes rendelkezéseket megvizsgálva azt láthatjuk, hogy azok a közvetítés általános kereteiről rendelkeznek, külön szabályokat nem tartalmaznak az elektronikus közvetítői, értékesítési tevékenységre vonatkozóan.

Az eredetileg személyes értékesítésre létrehozott szabályozás egyes rendelkezéseinek elektronikus felületekre történő alkalmazási módja adott esetekben kérdéseket vethet fel. Megjegyzendő, hogy a biztosítási törvény csupán egy helyen említ személyes eljárási kötelezettséget, mégpedig - ügyféligény esetén - a biztosításközvetítő panaszkezelésére vonatkozóan. A jelenlegi szabályozásról az azonban mindenképp elmondható, hogy bizonyosfajta fogyasztóvédelmi

\section{A Biztosítási Index létrehozásával a Deloitte tavaly fiatalon elhunyt partnerének, Szép Péternek korábbi munkásságát kívánja tovább folytatni.}

alapelveket már most megfelelően érvényesít, amelyek érvényesülése alapkövetelmény, tekintet nélkül arra, hogy a közvetítési tevékenység személyesen vagy elektronikus úton valósul-e meg. Ezen túlmenően lehet szükséges abban gondolkodni, hogy mely eljárásokat szükséges aktualizálni az elektronikus felületekre vonatkozóan.

Összességében elmondható, hogy ambivalens, ám javuló percepciók jellemzik a lakosság megítélését a biztosítókkal kapcsolatban. A biztosításokkal, illetve biztosítókkal kapcsolatos attitüdök alapvetően heterogének a lakosság körében, több kérdésben is látszik a háztartások megosztottsága. A következőkben összefoglaljuk a felmérés legfrissebb eredményeit. 


\section{Biztosítási termékek penetrációja, igénybevétele}

A kutatás több alapkérdést is vizsgál a biztosítási termékek darabszámával és penetrációjával kapcsolatban. Ezekből az látható, hogy a felnőtt magyar lakosság nagyjából kétharmada rendelkezik valamilyen biztosítási termékkel, a legnépszerủbb termék a lakásbiztosítás (a mintában szereplők 51\%-a biztosította ingatlanját), de gyakori még a lakosság körében a gépjármű-felelősségbiztosítás (29\%). A harmadik legnépszerűbb terméket pedig az életbiztosítás jelenti, ezzel a válaszadók 18 százaléka rendelkezett (11. ábra).

11. ábra: Biztosítások gyakorisága a felnőtt magyar lakosság körében 2015-ben

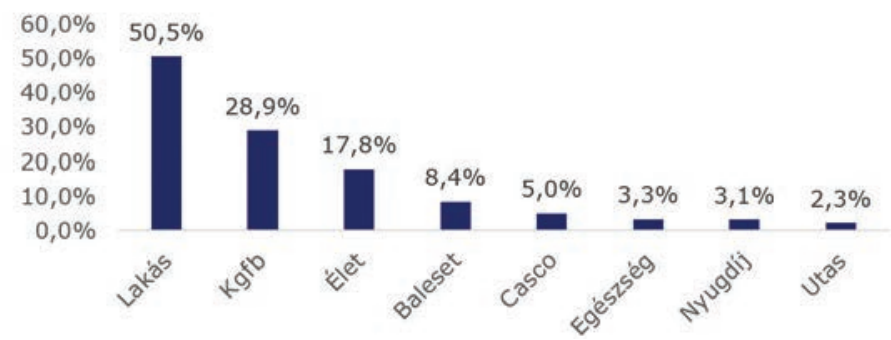

Forrás: Biztositási Index

A lakosság biztosítási termékeket érintő termékismerete a felmérés alapján meglehetősen magas, a legismertebb termékek, a lakás-, élet- és gépjármű-felelősségbiztosítások. A nagy, hosszabb ideje a piacon levő biztosítók portfólióinak jelentős része öt évnél idősebb a kutatás alapján. A legnagyobb társaságok esetében átlagosan az összes biztosítási termékre vonatkozóan az ügyfelek nagyjából harmada, lakásbiztosítás esetében több mint a fele öt évnél régebben kötötte meg biztosítását.

Az adott biztosítónál lévő, egy ügyfélre jutó biztosításszám átlagosan 1,5 darab. Ez az érték meglehetősen alacsony. Ennek egyrészről oka lehet, hogy egy ügyfél több biztosítóval is szerződésben állhat, ám ez az ügyfél számára nem feltétlenül előnyös, hiszen eleshet a biztosítók által kínált, több termék igénybevétele esetén járó kedvezményektől. Az alacsony értékek másik potenciális oka, hogy a biztosítással rendelkező ügyfelek alapvetően valóban ilyen kevés biztosítási terméket vesznek igénybe. $\mathrm{Az}$ alacsony átlagos biztosításszám ebből fakadóan jelentős keresztértékesítési potenciált rejthet magában.
A Biztosítási Index kitér arra is, hogy a biztosítottak a piac melyik szegmensét tartják a leginkább kompetitívnek, melyik termék esetében a legnagyobb az esélye annak, hogy megfelelő ajánlat esetén szolgáltatót váltsanak. Az eredmények azt mutatják, hogy ezek a piaci szegmensek a kötelező biztosítások, lakásbiztosítások és az utasbiztosítások piacát érintik, míg a biztosítás megszüntetésére vonatkozó tervek a casco és egészségbiztosítás terén a leggyakoribbak.

A 12. ábra a biztosítással rendelkező lakosok bizonyos demográfiai jellemzőit mutatja be életkor, végzettség, státusz, illetve családi állapot mentén. Összességében a biztosítással rendelkezők több mint fele 50 évnél idősebb, illetve a legalább érettségivel rendelkezők mintegy 60 százaléka használ biztosítási terméket. Érdemes kiemelni még más demográfiai jellemzőket is, amelyek megléte esetén adott személy nagyobb eséllyel vesz igénybe valamilyen, biztosító által nyújtott szolgáltatást:

- a magasabb jövedelemmel rendelkezők,

- a házasok,

- az aktív keresők,

- a városi lakosság körébe tartozók.

12. ábra: Biztosítással rendelkezők demográfiai eloszlása (\%)

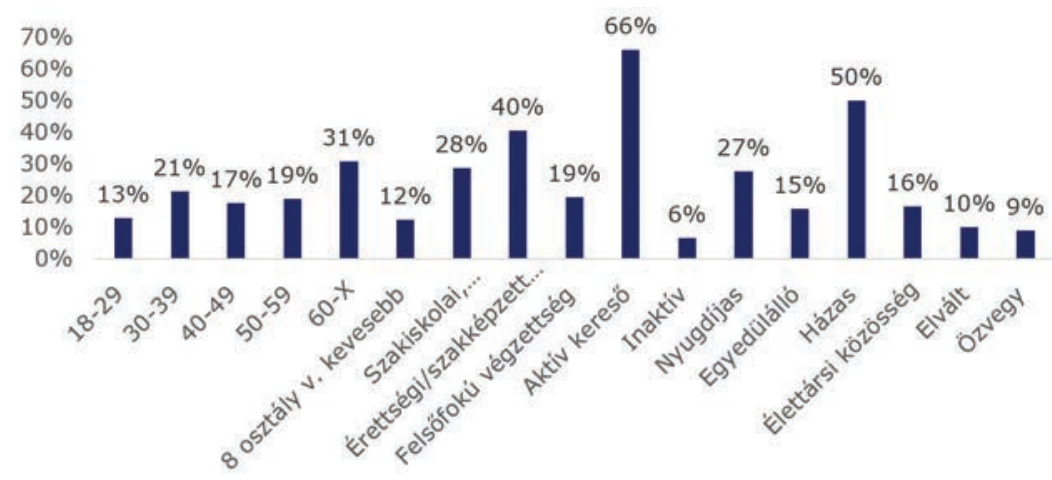

Forrás: Biztosítási Index

A 13. ábra két része a KSH adatait és a reprezentatív felmérés eredményeit veti össze bizonyos demográfiai szempontok alapján. Az elemzés célja, hogy bemutassa, mely szegmensekben, mely demográfiai para méterekkel bíró lakossági csoportokban lenne lehetőség a szolgáltatásokat igénybe vevők arányának növelésére, azaz azonosítsa a biztosítási szempontból alulpenetrált rétegeket. 
13. ábra: Biztosítással rendelkezők aránya korcsoport és végzettség alapján
Biztositíssal rendelkezök aránya a válaszadók életkorú népességen belǘ

$$
\text { - Biztositíssel rendelkezök aránya }
$$$$
\text { "Korcsoport aránya a 18-X népességen bell }
$$

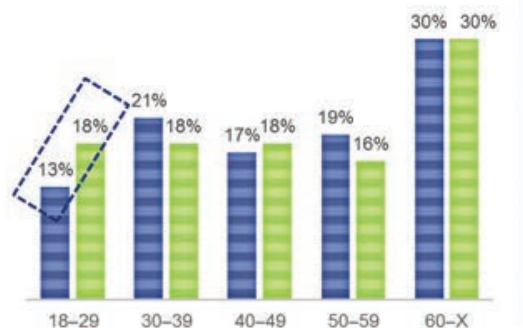

\section{Biztositással rendelkezök aránya végzettség szerint és a $15-74$ eves népesség megosz}

\section{Bizlositassar rendelikezók aranya}
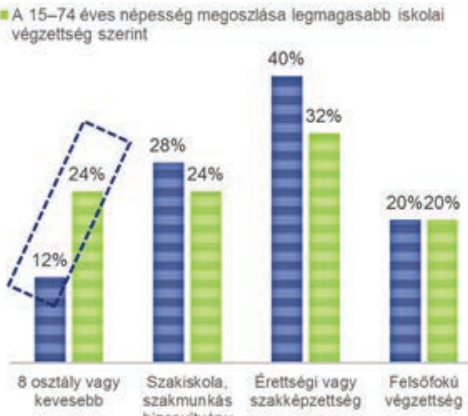

Forrás: Biztositási Index

A 13. ábrán látható, hogy három esetben is szignifikáns eltérés van a biztosítást igénybe vevők teljes mintán belüli és az adott demográfiai csoport teljes lakosságon belüli arányában. Két esetben alulpenetrált csoportokról beszélhetünk: a 18-29 éves lakosság csoportja, illetve a 8 vagy kevesebb osztályt elvégzők rétege egyértelműen alulbiztosított, ugyanakkor az érettségizett/ szakképzettséggel rendelkezők között felülreprezentált a biztosítottak köre.

A regionális eloszlásokat vizsgálva a 14. ábrán közel hasonló értékek láthatóak a KSH és a Biztosítási Index adatai között, a relatíve legmagasabb biztosítási alulpenetráltsági értéket Közép-Magyarország esetében tapasztaljuk. A családi állapot tekintetében a házasságban élők felülreprezentáltak a biztosításokkal rendelkezők körében, míg a nőtlen/hajadon státuszúak rétege alulbiztosítottnak mondható

\section{Biztosítási termékek, biztosítási szolgáltatások megítélése}

A kutatás első részében alapvető attitűdbeli kérdéseket tettek fel a lakosságnak. Ezek a következö területeket fedik le:

- Biztosításkötés fontosságának megítélése. Öt különböző kérdés eltérő szempontokból vizsgálja a biztosítási termékválasztás fontosságát, valamint a cégekkel kapcsolatos percepciókat a várható fizetési térítés tekintetében.

- Öngondoskodás és nyugdíjas évekre való felkészülés. Ezekben a kérdésekben az életszakasz és biztosításkötés közötti összefüggések, valamint az időskori évekről való gondoskodás fontossága kerül középpontba.

- Biztosítás bonyolultsága. Az ide vonatkozó pontok az igénybevétel összetettségére kérdeznek rá, illetve a percepciókat kutatják a biztosításkötés folyamatának összetettségével kapcsolatban.

- Árral kapcsolatos percepciók. A biztosítási termékek jelenlegi díjazását/árazását taglaló kérdések tartoztak ebbe a csoportba.

Az alábbiakban a fenti területek eredményei, illetve a kapott válaszok kerülnek összefoglalásra.

14. ábra: Biztosítással rendelkezők aránya regionális megoszlás szerint, illetve családi állapot alapján

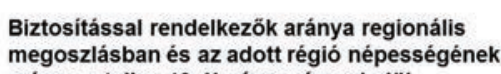
megoszlásban és az adott régió népessét

- Biztositíssal rendelikezök aranny a

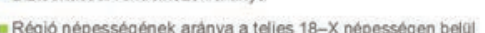

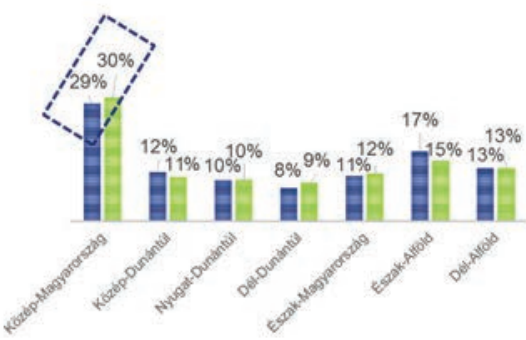

Forrás: Biztosítási Index

\section{Biztosításkötés fontosságának megítélése}

Az iskolai végzettség növekedésével párhuzamosan a válaszadók egyre inkább fontosnak tartják lakásbiztosítás megkötését: míg a főiskolai vagy egyetemi diplomával rendelkezők körülbelül 70 százaléka felelötlenségnek tartja, ha valaki nem rendelkezik biztosítással az általa tulajdonolt lakásra, például a nyolc osztályt és annál kevesebbet végzett válaszadók között ez az arány csupán 40 százalékos. A gimnáziumi érettségivel rendelkezők 59 százaléka tartja fontosnak lakásbiztosítás kötését.

Az életkor és a lakásbiztosítást fontosnak tartók között nem tapasztalható hasonló összefüggés, a minta alapján ugyanakkora arány tartja fontosnak a terméket minden életszakaszban. Ha a háztartások jövedelme alapján különítjük el az egyes demográfiai csoportokat egymástól, akkor azt tapasztaljuk, hogy a jövedelem növekedésével párhuzamosan nő a lakásbiztosítást fontosnak tartók aránya. A fenti párhuzamok, bár nem ilyen markánsan, de az összes biztosításra vonatkoztatva is megfigyelhetők. 
Bár a biztositók megítélése javulást mutat az utóbbi években, demográfiai hovatartozástól függetlenül még mindig viszonylag nagy azoknak az aránya, akik úgy vélik, hogy egy esetleges káresemény bekövetkeztével a biztosítók kibúinak a felelősség alól. A háztartás jövedelmétől függetlenül nagyjából a válaszadók harmada ért inkább egyet a fenti állítással. Az iskolai végzettség növekedésével párhuzamosan csökken az állítással egyetértők aránya, de még az egyetemi végzettséggel rendelkezőknek is közel ötöde vélekedik negatívan a biztosítókról.

Regionális megoszlás alapján szembetűnik a budapestiek részéről kialakult negatív attitűd: az ott élő válaszadók közel harmada gondolja, hogy a biztosítók káresemény felmerülésekor elhárítják a felelősséget. Ezt támasztja alá, hogy - a többi régióhoz képest - Budapesten magas azoknak a válaszadóknak az aránya (41\%, szemben a többi régióra vonatkozó átlagosan 33\%os értékkel), akik csak akkor kötnének biztosítást, ha az kötelezö lenne számukra. Ugyanakkor ez érdekes ellentét annak fényében, hogy általában a városi , magasabb jövedelemmel rendelkező lakosság körében magasabb a biztosítási termékek igénybevételi hajlandósága.

\section{Öngondoskodás és a nyugdíjas évekre való felkészülés}

Mindenképpen pozitív kép a válaszok alapján, hogy a megkérdezettek több mint fele az öngondoskodás mellett tette le a voksát, ami egyre tudatosabb fogyasztói attitűdöt feltételez. Ebben a folyamatban a biztosítók kulcsfontosságú szerepet töltenek be, hiszen releváns alternatívát nyújthatnak a fogyasztóknak az állami nyugdíjrendszer mellett.

\section{A megkérdezettek több mint fele az öngondoskodás mellett tette}

\section{le a voksát, ami egyre tudatosabb fogyasztói attitüdöt feltételez.}

Szinte minden egyes alcsoportban - függetlenül a demográfiai csoportoktól, illetve az egyes csoportokon belüli hovatartozástól - a válaszadók több mint fele vélekedik úgy, hogy az emberek nem bízhatnak abban, hogy időskorukra megfelelő mértékű nyugdíjban részesülnek, így elengedhetetlen számukra az öngondoskodás. Ebben a kérdésben tehát viszonylag egységesen gondolkodik a társadalom.

\section{Biztosításkötés bonyolultsága}

Érdekes megvizsgálni a biztosítási termékek bonyolultságát bemutató kérdésre adott válaszokat is. Látható, hogy az életkor előrehaladtával a válaszadók nehezebben értik meg az egyes termékeket, míg a 30-39 éves korosztály 22 százaléka küzd hasonló problémával, addig a 60 év feletti válaszadók negyven százaléka vallja ezt. Az iskolai végzettség demográfiai mutatója alapján tapasztalhatóak a leginkább szignifikáns különbségek: a 8 osztályt végzettek között a válaszadók több mint fele nem volt tisztában a biztosítási termékek mögöttes tartalmával, míg a föiskolai diplomával rendelkezők között csupán 20 százalék ez az arány. Azoknak, akik egyetemi diplomával rendelkeznek, csak 7 százaléka volt gondban az egyes termékek értelmezésével.
Családi állapot tekintetében az özvegy státuszú válaszadók között volt a legmagasabb ez az arány, ami összhangban állhat az életkor és a termékek közti eligazodás képességének összefüggésével. A magasabb jövedelműek körében - mind háztartásonként értelmezett, mind pedig egyéni jövedelem esetében - jelentősen csökken a termékeket bonyolultnak tartók aránya. A 300 ezer forint feletti háztartásonkénti jövedelemmel bírók csupán 15 százaléka értett egyet azzal az állítással, hogy nehezen igazodik ki a biztosítások között.

\section{Árral kapcsolatos percepciók}

A felmérés vizsgálta azt is, hogy a mintában szereplők limitált anyagi lehetőségei mennyiben tántorítják el őket a szolgáltatás igénybevételétől. Demográfiai hovatartozástól függetlenül a megkérdezettek jelentős része, még az egyetemi végzettséggel rendelkezőknek is valamivel több, mint a harmada gondolta úgy, hogy - bár szívesen kötne további biztosításokat - anyagi lehetőségei miatt nem engedhetik meg maguknak további szolgáltatás igénybevételét.

Némileg meglepő, hogy még a legmagasabb, háztartásonként 300 ezer forintos jövedelmet meghaladó bevétellel rendelkező válaszadóknak is majd 40 százaléka gondolja, hogy pénztárcájukhoz mérten túlzottan drágák ezek a szolgáltatások. Ha feltételezzük, hogy az adott évben eltöltött üdülések száma erősen összefügg a válaszadó anyagi lehetőségeivel, akkor azt látjuk, hogy azok körében, akik évente négyszer vagy többször voltak üdülni, 25 százalék azoknak az aránya, akik szívesen kötnének több biztositást, de egyszerüen nem engedhetik meg maguknak.

\section{Biztosítók általános megítélése}

A biztositók megítélése a magyarországi bankokkal és hitelintézetekkel összevetve viszonylag kedvező, azonban a fejlődésre még bőven van lehetőség. A devizahitelekkel kapcsolatos problémák és a brókerbotrány külső tényezőitől azonban nem szabad eltekintenünk: az elmúlt években a közvélemény szinte mindenhol a bankok ellen fordult, ami részben kihatott a biztosítókra is. A biztosítók megítélésével kapcsolatban nemcsak az általános megítélést foglaltuk össze, hanem külön részben tértünk ki azokra a kritikus pontokra, amelyek mentén elsősorban a lakosság megítéli a biztosítók tevékenységét.

A biztosítótársaságok lakossági megítélése az elmúlt három évben folyamatos javulást mutat: míg 2012 első negyedévében a lakosság 31 százaléka gondolta úgy, hogy ezek a társaságok korrektül bánnak ügyfeleikkel, addig 2015 második negyedévében ez az arány már 40 százalékra nőtt. (Ezzel szemben - valószínűleg elsősorban devizahitelekkel kapcsolatos problémák miatt - például a bankok megítélése stagnált a vizsgált időszak alatt.) Míg a megkérdezettek közel 60 százaléka gondolta 2012-ben a biztosítók tevékenységét fontosnak, addig ez az arány 2015-re 72 százalékra gyarapodott. A felmérésekből alapvetően az látszik, hogy minden területen javulást mutat a biztosítók, illetve szolgáltatásaik megítélése.

A termék, az ügyintézés, illetve a díjjal kapcsolatban a megkérdezettek többsége (65-70\%) elégedett a 2012-2015-ös adatokat figyelve. Ezzel párhuzamosan a biztosítással rendelkező ügy- 
felek többsége nem kíván váltani, illetve új terméket vásárolni, amiből arra következtethetünk, hogy az ügyelek többsége hűséges, vagy a biztosítóváltást túl bonyolultnak tartja.

\section{Termék életciklus alapú megközelítés}

A termékek életciklusai alapján összegyűjtöttük azon befolyásoló tényezőket, amelyeknek ugyancsak befolyásoló hatásuk lehet a biztosítótársaságok megítélésére.

Értékesítés - A biztosítói termékek eladásában, főleg az élet ág területén még mindig nagyobb szerepet ölt a személyes értékesítés, ahol a biztosítóknak kellőképpen megválasztott ügynököket, illetve partnereket kell találniuk, akik megfelelően, az ügyfél igényét figyelembe véve képesek a biztosítót képviselni és az adott terméket, szolgáltatást eladni. Az értékesítéshez ugyancsak elengedhetetlenek az értékesítést támogató rendszerek, amelyek nagy segítséget jelenthetnek az értékesítőnek, hogy az ügyfél igényének megfelelő terméket tudjon ajánlani. Jelenleg már nagyon sok olyan értékesítéstámogató rendszer létezik, amely segíti az ügyfeleknek az egyes biztosítási termékek megértését, leegyszerüsítve a bonyolultnak hitt termékeket.

\section{A biztosítói termékek eladásában, föleg az élet ág területén még} mindig nagyobb szerepet ölt a személyes értékesités.

A nem-életbiztosítói termékek esetében egyre nagyobb teret hódít az elektronikus csatornán történő eladás, azonban ez is csak úgy tartható fent, ha a biztosító az ügyfeleknek olyan egyszerü és informatív oldalt is készít, amely alapján az ügyfél könnyen vásárolhat terméket.

Ugyanebben a pontban említenénk meg, hogy jelenleg az értékesítésnél keletkező hatalmas mennyiségű dokumentum ugyan az ügyfél érdekeit képviseli, de nem segíti az átláthatóságot, és fokozza a termék bonyolultságát. Képzeljük el, hogy egy egyszerű unit-linked és/vagy hagyományos életbiztosítási termék megkötésének alkalmával jogszabályi kötelezettség alapián az ügyfélnek temérdek mennyiségű dokumentációt adnak át (átlagosan az ajánlaton kívül 15-20 A4-es oldalt vagy annál is többet), ami rengeteg információt tartalmaz. Ezt átnézni és egyáltalán megérteni még az átlagos vagy annál jobb pénzügyi tudással rendelkező ügyfél számára is igen nagy erőfeszítésbe kerül.

Elbírálás - Az eladást követően nagy a back office jelentősége, hiszen még egy jól eladott terméknél is rongálja az ügyfélélményt, ha hosszú és bonyolult procedúra követi a már átbeszélt és papíron eladott terméket. Ezért is fontos, hogy az ügyfél lehetőség szerint már csak a kötvényt kapja meg.

Meglévő termék ügyintézése - Minél inkább az egységes ügyintézésre kellene törekedni az élet és nem-élet termékek esetében is. Itt az ügyfeleket mindenképpen arra kell ösztönözni, hogy egyedi azonosítóval a biztosítóportálon hajtsák végre a kívánt tranzakciót.
Tapasztalataink alapján a termékek területén nagyon nagy változás figyelhető meg az egyes biztosítótársaságoknál. A termékek egyszerűsítése érdekében egyre inkább egy alaptermék létrehozása a jellemző, amely az ügyfél igényének megfelelően alakítható át a különböző kiegészítő, moduláris biztosításokkal, az értékesítéstámogató rendszer pedig egyszerűen és érthető módon modellezi le az ügyfél számára.

Jelenleg elmondható, hogy Európa-szerte nagy hangsúlyt fektetnek a biztosítási termékek szabályozására, a mivel a megtakarítási célú életbiztosításokat igyekeznek az ügyfelek számára átláthatóbbá tenni. Ezen szabályozói intézkedések terén már nagyon sok példa látható, a minimális változtatástól kezdve a piac komoly szabályozásáig. Az MNB és a magyar kormány több átgondolt, a biztosítási piac működését is figyelembe vevő intézkedésen keresztül igyekszik az úgynevezett etikus életbiztosítási koncepcióval ügyfél- és EU-konformmá tenni ezeket a megtakarítási termékeket.

\section{Fizikai csatornahasználat jelentősége és lakossági percepció}

Pontos adatok jelenleg nem állnak rendelkezésre azzal kapcsolatban, hogy Magyarországon milyen módon oszlik meg az értékesítés az egyes csatornákon keresztül, de az a Biztosítási Indexből mindenesetre kiderül, hogy többségében még mindig fizikai csatornákon (például ügynök, bróker, alkusz) keresztül vásárolnak biztosítást, legyen az élet vagy nem-életbiztosítási termék.

Meglátásunk szerint a közeljövőben nem lesz nagy változás az értékesítési csatornák megoszlása terén, nem elhanyagolható azonban, hogy az internettel rendelkező lakosok száma egyre nagyobb, és a háztartások vásárlási szokása ennek megfelelően változik. A magyar piacon a biztosítók termékeinek többsége megvásárolható online csatornán keresztül is (ezek jórészt nem életbiztosítások), azonban van olyan biztosító, akinek bonyolultabb életbiztosítási terméke is megjelent már online (csekély értékesítési eredménnyel).

A biztosítóknak törekedniük kell arra, hogy minél több termékük jelenjen meg online piacon, amit így az ügyfél egyszerűen meg tud vásárolni. A meglévő biztosítással rendelkező ügyfeleknek (élet és nem-életbiztosítási termékek esetében) biztosítani kell a megfelelő biztonsági feltételek mellett a teljes ügyfélkiszolgálást, így növelve az ügyfélélményt és csökkentve a biztosítási operációs költségeket.

Az értékesítési csatornák tekintetében még mindig magas a hagyományos csatornák szerepe: az ügyfelek jelentős része továbbra is a biztosító irodájából, annak ügyfélszolgálatától veszi igénybe a szolgáltatást. Az online tájékozódók jellemzően a budapesti közigazgatási régióban élnek, 18 és 39 éves kor közöttiek, 300 ezer forintos vagy afeletti háztartási jövedelemmel rendelkeznek. Érdemes lehet erre az értékesítési szegmensre koncentrálni, a felmérésben részt vevők közel ötöde használja az online csatornákat a szolgáltatás igénybevételére. 


\section{Összegzés gyanánt}

A magyarországi biztosítási penetráció a háztartások körében historikusan alacsonyabb értéket mutat nemcsak az európai, hanem a visegrádi országok átlagához képest is. Holott ezt önmagában a gazdasági fejlettség vagy a háztartások pénzügyi vagyonának nagysága közel sem magyarázza. Éppen emiatt tartjuk fontosnak a kulturális különbségeknek, a lakosság pénzpiaci szokásainak kutatását, kiemelve ezen belül a biztosításpiaci megítélés és termékhasználat részletes elemzését. Célunk a kutatások segítségével kellő minőségű és hiteles információ nyújtása a piaci változásokról, az ügyfelek és általában a keresleti oldal működésének jobb megértése, valamint a közös gondolkodás elősegítése a piac szereplőivel a lehetséges megoldásokról.

\section{HIVATKOZÁSOK}

${ }^{1}$ Forrás: EUROSTAT, Financial balance sheets adatbázis

\section{IRODALOMJEGYZÉK}

Deloitt-Scale I. Biztositási index felmérés, 2015

(2015, http://ec.europa.eu/eurostat/web/sector-accounts/data/database an-insurance-figures 